\title{
PAPERS
}

\section{Chemokines in the gastric mucosa in Helicobacter pylori infection}

\author{
Y Yamaoka, M Kita, T Kodama, N Sawai, T Tanahashi, K Kashima, J Imanishi
}

\begin{abstract}
Background-Although chemokines have been suggested to play an important role in Helicobacter pylori associated gastritis, few studies have investigated the role of chemokines other than interleukin 8 (IL-8) in gastric mucosa.

Aims-To investigate the expression and production patterns of various chemokines using gastric biopsy specimens. Methods-In 192 patients, expression patterns of C-X-C chemokines (IL-8 and growth regulated $\alpha(\mathrm{GRO} \alpha)$ ) and C-C chemokines (regulated on activation, normal $T$ cell expressed and presumably secreted (RANTES), monocyte chemotactic and activating factor (MCAF), macrophage inflammatory protein $1 \alpha(\mathrm{MIP}-1 \alpha)$, and MIP-1 $\beta$ ) were examined using reverse transcription polymerase chain reaction (RT-PCR) and enzyme linked immunosorbent assay (ELISA). $\operatorname{cag} A$ gene was identified using PCR.
\end{abstract}

Results-H pylori infection was associated with increased rates of expression of mRNA for IL-8, GRO $\alpha$, RANTES, and MIP-1 $\alpha$ and with increased levels of mucosal IL-8 and GRO $\alpha$. IL-8 and GRO $\alpha$ levels correlated with the density of $H$ pylori in both the antrum and corpus. The levels of these chemokines correlated with cellular infiltration in the antrum but not the corpus. $\operatorname{cag} A$ gene positive $H$ pylori infection was associated with increased rates of expression of mRNA for IL-8 and GRO $\alpha$ and with increased levels of these chemokines.

Conclusion-H pylori infection is associated with increased expression rates and production of C-X-C chemokines (IL-8 and GROa), but not with increased production of C-C chemokines. Although $H$ pylori infection is associated with increased C-X-C chemokines in the antrum and corpus, there is a difference in the inflammatory response between these two areas of the stomach.

(Gut 1998;42:609-617)

Keywords: Helicobacter pylori; chemokines; interleukin 8; GRO $\alpha$
Helicobacter pylori is a Gram negative bacterium thought to cause chronic gastritis, peptic ulcer, ${ }^{12}$ and gastric cancer. ${ }^{34} \mathrm{H}$ pylori associated gastritis is fundamentally a bacterial infection of the gastroduodenal mucosal surface and as such is characterised by mucosal infiltration of polymorphonuclear leucocytes (PMNs) and mononuclear cells (MNCs). ${ }^{5}$ Cure of the infection results in healing of the gastritis and notable reduction in mucosal inflammation. The migration and activation of inflammatory cells into the mucosa is thought to be related to expression of various cytokines. ${ }^{6-15}$ A number of studies have investigated interleukin 8 (IL-8), which is known to be a neutrophil chemotactic factor, ${ }^{16}{ }^{17}$ and have shown an association between levels of $H$ pylori infection and IL-8 mRNA $^{111214}$ or IL-8 protein. ${ }^{7-101315}$

Cytokines showing leucocyte chemotactic activities, including IL-8, are referred to as chemokines. ${ }^{18}{ }^{19}$ More than 20 members of the chemokine superfamily have been identified and shown to be involved directly or indirectly in inflammatory responses. Chemokines are classified into two major families on the basis of the arrangement of the first two of four conserved cysteine residues. The C-X-C chemokines consist of those members whose first two cysteines (C) are separated by one amino acid (X), while in the $\mathrm{C}-\mathrm{C}$ chemokines the first two cysteines are adjacent to one another. In general, C-X-C chemokines mainly show chemotactic activities for neutrophils but not monocytes, whereas C-C chemokines show chemotactic activities for monocytes and lymphocytes but have little effect on neutrophils. ${ }^{20}$ The former group includes IL-8 and growth regulated (GRO), and the latter group includes regulated on activation, normal $\mathrm{T}$ cell expressed and presumably secreted (RANTES), monocyte chemotactic and activating factor (MCAF), macrophage inflammatory protein $1 \alpha(\mathrm{MIP}-1 \alpha)$, and MIP- $1 \beta$. Although IL- 8 is closely associated with $H$ pylori infection, few studies have investigated the relation between $H$ pylori infection and chemokines other than IL-8.

To begin to clarify the relation between $H$ pylori infection and chemokines, we examined chemokine expression and production patterns in gastric mucosa by reverse transcription polymerase chain reaction (RT-PCR) and enzyme linked immunosorbent assay (ELISA) (111D), 2002 Holcombe USA. 
using gastric biopsy specimens. In general, gastric mucosal inflammation caused by $H$ pylori is more severe in the antrum than that in the corpus. $^{21}{ }^{22}$ We therefore investigated the expression of chemokines in the antrum and corpus in patients with and without $H$ pylori infection.

\section{Materials and methods}

PATIENT POPULATION

A total of 192 patients (110 men and 82 women; age range 21-81 years, mean 54.7 years) were studied; 172 were consecutive symptomatic adults who underwent endoscopy between October and December 1995. In order to examine the relation between $H$ pylori and gastric cancer, 25 patients with gastric cancer, who underwent endoscopy between January and May 1996, also participated in this study. No patient had received non-steroidal anti-inflammatory drugs, proton pump inhibitors, or antibiotics within the previous three months. There was no overlap between subjects in this and in our previous studies. Endoscopic findings included: normal mucosa, 10 patients; gastritis without ulcer, 86 patients; gastric ulcer, 41 patients; duodenal ulcer, 30 patients; and gastric cancer, 25 patients. Ninety four patients were smokers. Informed consent was obtained from all patients and the protocol was approved by the ethics committee of Kyoto Prefectural University of Medicine.

Four biopsy specimens were taken from both the antrum (pyloric gland area) and corpus (fundic gland area); two were used for histological examination, one for $H$ pylori culture and cytokine protein measurement, and one for cytokine mRNA measurement. Biopsy specimens were taken at least $2 \mathrm{~cm}$ from ulcers or tumours in the cases of gastric ulcer and gastric cancer.

The presence of $H$ pylori was determined by culture and histological examination. Patients were classified as $H$ pylori positive if at least one of the examinations gave a positive result. Some of the $H$ pylori positive patients who had gastric ulcer or duodenal ulcer were treated with omeprazole $20 \mathrm{mg}$ once daily, amoxycillin $2000 \mathrm{mg}$ twice daily, and clarithromycin 400 mg twice daily, for two weeks. Four weeks after cessation of treatment, the patients were examined endoscopically again and biopsy specimens were taken as before. ${ }^{13} \mathrm{C}$ urea breath test was also performed, and successful eradication of $H$ pylori was determined if all test results were negative.

\section{HISTOLOGY}

The biopsy specimens were fixed in $10 \%$ buffered formalin, oriented on edge, embedded in paraffin wax, cut in sequential $4 \mu \mathrm{m}$ sections, and stained with haematoxylin and eosin $(\mathrm{H} \& \mathrm{E})$ and modified Giemsa stains. We usually cut three to five serial sections for one specimen and multiple high power fields were examined. Virtually all specimens included surface epithelium and muscularis mucosa. Specimens were examined by one experienced histologist blinded to the patient's clinical diagnosis or the characteristics of the $H$ pylori strain. The following features were evaluated: MNC infiltration, PMN infiltration, and density of $H$ pylori. All variables were graded using the visual analogue scale graded from 0 to 3 for biopsy specimens from each site according to the Updated Sydney system. ${ }^{23}$ For analysing the relation between the histological findings and the expression patterns of chemokines, we used the biopsy specimens from a mucosal site adjacent to the site where the biopsy specimens for chemokine measurements were obtained. MNC infiltration was scored as follows: $0=$ occasional lymphocytes and plasma cells at a level considered normal; $1=$ mild focal increase in MNC numbers; 2 = definite infiltrate with MNCs isolated from each other; and $3=$ diffuse MNC infiltrate. PMN infiltration was scored as follows: $0=$ no neutrophils; $1=$ infiltrate only in the lamina; $2=$ infiltrate within the epithelium; and $3=$ infiltrate within the foveolar lumen. The density of $H$ pylori was scored based on the average density on the surface and the foveolar epithelium. If areas with widely different scores were present on the same specimen, an average based on the general evaluation of the sample was used by the observer. If intestinal metaplasia was present, only areas without metaplasia were evaluated for the presence of $H$ pylori.

\section{H PYLORI CULTURE}

Biopsy specimens were placed in $1.5 \mathrm{ml}$ of phosphate buffered saline (PBS; $\mathrm{pH} 7.4$ ), and were immediately homogenised using a tissue homogeniser (Kontes, Vineland, New Jersey, USA). Ten $\mathrm{ml}$ aliquots of homogenate supernatant were spread on Skirrow agar medium containing $8 \%$ horse blood, vancomycin (10 $\mathrm{mg} / \mathrm{ml})$, polymyxin $\mathrm{B}(2.5 \mathrm{U} / \mathrm{ml})$, and trimethoprim $(5 \mathrm{mg} / \mathrm{ml})$ and incubated at $37^{\circ} \mathrm{C}$ under microaerophilic conditions (AnaeroPack Systems; Mitsubishi Gas Chemical Co., Inc., Osaka, Japan) for up to five days. The organisms were identified as $H$ pylori by Gram staining, colony morphology, and positive oxidase, catalase, and urease reactions. The strains were cultured again at $37^{\circ} \mathrm{C}$ under microaerophilic conditions in brain heart infusion broth (Nissui Co., Ltd., Osaka, Japan) containing $5 \%$ horse serum for 24 to 48 hours on a shaker, and aliquots were stored at $-80^{\circ} \mathrm{C}$ in brain heart infusion broth containing 15\% horse serum and $15 \%$ glycerol.

PREPARATION OF GNOMIC DNA FROM CLINICAL ISOLATES

The culture medium was centrifuged for five minutes at $10000 \mathrm{~g}$ and the bacterial pellets were washed three times with PBS ( $\mathrm{pH}$ 7.4). The pellets were each suspended in $200 \mathrm{ml}$ of distilled water and were boiled for 10 minutes. The supernatants, obtained by centrifugation (10000 $\mathrm{g}$ for five minutes), were stored at $-20^{\circ} \mathrm{C}$ until use as PCR templates.

PREPARATION OF RNA AND CDNA FOR CHEMOKINE mRNA MEASUREMENT

The biopsy specimens were immediately placed in guanidine isothiocyanate buffer, frozen on dry ice, and stored at $-80^{\circ} \mathrm{C}$ until 
use. Samples were homogenised using a tissue homogeniser (Kontes), and total RNA was extracted by the acid guanidinium isothiocyanate-phenol-chloroform method as described previously. ${ }^{24}$ Aliquots $(1 \mathrm{mg}$ ) of total RNA were incubated at $65^{\circ} \mathrm{C}$ for five minutes, chilled on ice, and reverse transcribed in a final volume of $10 \mathrm{ml}$ of a solution containing 50 $\mathrm{mmol} / 1 \mathrm{Tris}-\mathrm{HCl}(\mathrm{pH}$ 8.3), $75 \mathrm{mmol} / \mathrm{l} \mathrm{KCl}, 3$ $\mathrm{mmol} / 1 \mathrm{MgCl}_{2}, 10 \mathrm{mmol} / 1$ dithiothreitol, 200 $\mathrm{mmol} / 1$ each of deoxyadenosine triphosphate, deoxycytidine triphosphate, deoxyguanosine triphosphate, and deoxythymidine triphosphate (Pharmacia Biotech AB, Uppsala, Sweden), $1 \mathrm{mmol} / 1$ oligo(dT) 16 primer, 20 units RNAsin (Ribonuclease inhibitor; Toyobo Co., Ltd, Tokyo, Japan), and 100 units of MoMuLV RNase $\mathrm{H}^{-}$reverse transcriptase (BRL Co., Gaithersburg, Maryland, USA). The mixture was incubated at $43^{\circ} \mathrm{C}$ for 90 minutes, heated to $95^{\circ} \mathrm{C}$ for 10 minutes, and stored at $-20^{\circ} \mathrm{C}$ until use.

POLYMERASE CHAIN REACTION

Bacterial DNA and cDNA from biopsy specimens were denatured by heating to $95^{\circ} \mathrm{C}$ for 10 minutes and cooled on ice for five minutes. Bacterial DNA and cDNA $(5 \mathrm{ml})$ were added to $50 \mathrm{ml}$ reaction mixtures containing $5 \mathrm{ml} \mathrm{10x}$ PCR reaction buffer $(500 \mathrm{mmol} / \mathrm{K} \mathrm{KCl}, 100$ $\mathrm{mmol} / \mathrm{l}$ Tris- $\mathrm{HCl}(\mathrm{pH} 8.8), 15 \mathrm{mmol} / 1 \mathrm{MgCl}_{2}$, $1 \%$ Triton X-100, $200 \mathrm{mmol} / 1$ each of deoxyadenosine triphosphate, deoxycytidine triphosphate, deoxyguanosine triphosphate, and deoxythymidine triphosphate, $200 \mathrm{nmol} / 1$ of each primer, and 1.0 unit Taq DNA polymerase (Boehringer, Mannheim, Germany), and $\mathrm{H}_{2} \mathrm{O}$ ). Amplification was performed using a Takara PCR Thermal Cycler 480 (Takara Biomedicals, Otsu, Japan) for 35 cycles (for chemokine PCRs) or 30 cycles (for 16S rRNA and $\operatorname{cag} A$ PCRs), each of which consisted of one minute at $95^{\circ} \mathrm{C}$ for denaturation, one minute at $60^{\circ} \mathrm{C}$ (for chemokine PCRs) or $50^{\circ} \mathrm{C}$ (for $16 \mathrm{~S}$ rRNA and $\operatorname{cag} A$ PCRs) for annealing, and one minute at $72^{\circ} \mathrm{C}$ for extension. The final cycle included an extension step for seven minutes at $72^{\circ} \mathrm{C}$ to ensure full extension of the product. Aliquots $(10 \mathrm{ml})$ of each PCR product were analysed by electrophoresis on $1.5 \%$ agarose (Dojin Chemical Co., Ltd, Kyoto, Japan) gels containing ethidium bromide, and the bands were examined under ultraviolet light for the presence of the amplified DNA.

Oligonucleotide primers were designed based on previous studies. ${ }^{1525-28}$ The sense and

Table 1 Human chemokine specific oligonucleotide primers for RT-PCR

\begin{tabular}{|c|c|c|c|}
\hline Chemokine & Primer & Nucleotide & $c D N A(b p)$ \\
\hline \multirow[t]{2}{*}{ IL-8 } & Sense & GCTTTCTGATGGAAGAGAGC & \multirow[t]{2}{*}{585} \\
\hline & Antisense & GGCACAGTGGAACAAGGACT & \\
\hline \multirow[t]{2}{*}{ GRO $\alpha$} & Sense & TTGCAGACCCTGCAGGGAAT & \multirow[t]{2}{*}{184} \\
\hline & Antisense & TGGATTTGTCACTGTTCAGC & \\
\hline \multirow[t]{2}{*}{ RANTES } & Sense & TGCCTCCCATATTCCTCGG & \multirow[t]{2}{*}{211} \\
\hline & Antisense & CTAGCTCATCTCCAAAGA & \\
\hline \multirow[t]{2}{*}{ MIP-1 $\alpha$} & Sense & CCTTGCTGTCCTCCTCTGCA & \multirow{2}{*}{254} \\
\hline & Antisense & CACTCAGCTCTAGGTCGCTG & \\
\hline \multirow{2}{*}{ MIP-1 $\beta$} & Sense & TGTCTCTCCTCATGCTAGTA & \multirow[t]{2}{*}{233} \\
\hline & Antisense & GTACTCCTGGACCCAGGAT & \\
\hline \multirow[t]{2}{*}{ MCAF } & Sense & CAATAGGAAGATCTCAGTGC & \multirow[t]{2}{*}{188} \\
\hline & Antisense & GTGTTCAAGTCTTCGGAGTT & \\
\hline
\end{tabular}

antisense primers specific for each chemokine were designed to include at least one intron, permitting distinction between amplified cDNA and possible contaminating residual gnomic DNA. Table 1 shows chemokine specific oligonucleotide primers. $\beta$-Actin and $H$ pylori $16 \mathrm{~S}$ rRNA were assayed as positive controls for chemokine measurement and for the presence of $H$ pylori, respectively. In addition, $\operatorname{cag} A$ gene negative strains, G21, G50, and $2 \mathrm{U}$ (kindly provided by $\mathrm{Dr} \mathrm{J} \mathrm{E}$ Crabtree), were simultaneously assayed to check for contamination.

\section{CHEMOKINE PROTEIN MEASUREMENT}

For chemokine protein measurement, we used the same biopsy specimens as used for $H$ pylori culture. Biopsy specimens were placed in $1.5 \mathrm{ml}$ of PBS ( $\mathrm{pH}$ 7.4), and were immediately homogenised using a tissue homogeniser as described earlier. Aliquots of homogenate supernatants, obtained by centrifugation (10 $000 \mathrm{~g}$ for 10 minutes), were stored at $-80^{\circ} \mathrm{C}$ until assay for total proteins by a modified Lowry method and for chemokine protein by ELISA. IL-8, GRO $\alpha$, MIP- $1 \alpha$, and RANTES in biopsy homogenate supernatants were measured by ELISA using commercially available assay kits (Research and Diagnostic Systems, Minneapolis, Minnesota, USA). Assays were performed in duplicate according to the manufacturer's instructions. In our laboratory, the ELISA sensitivities of IL-8, GRO $\alpha$, MIP- $1 \alpha$, and RANTES were approximately $10 \mathrm{pg} / \mathrm{ml}$.

\section{STATISTICS}

The mucosal levels of IL-8, GRO $\alpha$, MIP- $1 \alpha$, and RANTES protein were expressed as $\mathrm{pg} / \mathrm{mg}$ biopsy protein, and data were expressed as median and range. As histological scores are non-parametric, these scores are presented as median rather than mean values. The two tailed Fisher's exact probability test was used to compare RT-PCR results between patient populations. This test was also used to compare differences of chemokine mRNA before and after treatment. Wilcoxon's matched pairs test was used to compare differences of chemokine protein before and after treatment. The relation between histological findings and the production of chemokines was assessed by Spearman's rank correlation coefficient. This test was also used to assess the relation between the production of IL- 8 and GRO $\alpha$. For the remaining statistical analyses, the Mann-Whitney U test for non-parametric data was used. A p value of less than 0.05 was accepted as statistically significant.

\section{Results}

H PYLORI INFECTION AND ENDOSCOPIC AND HISTOLOGICAL FINDINGS

Of the 192 patients examined, 131 (68.2\%) were positive for $H$ pylori (table 2). Of the 123 patients with positive culture for $H$ pylori, 114 $(92.7 \%)$ were positive for the $\operatorname{cag} A$ gene.

As expected specimens from patients with endoscopic normal mucosa without $H$ pylori had no infiltration of MNCs or PMNs and specimens from those with $H$ pylori infection 
Table 2 H pylori infection and endoscopic findings

\begin{tabular}{|c|c|c|c|c|c|c|}
\hline \multirow[b]{2}{*}{ Endoscopic findings } & \multicolumn{3}{|c|}{ H pylori positive } & \multirow[b]{2}{*}{$\begin{array}{l}\text { H pylori } \\
\text { negative }\end{array}$} & \multirow[b]{2}{*}{$\begin{array}{l}\text { H pylori } \\
\text { positive/total (\%) }\end{array}$} & \multirow[b]{2}{*}{$\begin{array}{l}\operatorname{cag} A^{+} /\left(\operatorname{cag} A^{+}\right. \\
\left.\text {and } \operatorname{cag} A^{-}\right)(\%)\end{array}$} \\
\hline & $\operatorname{cag} A^{+}$ & $\operatorname{cag} A^{-}$ & Not determined ${ }^{\star}$ & & & \\
\hline Chronic gastritis $(n=86)$ & 45 & 5 & 3 & 33 & 61.6 & 90.0 \\
\hline Gastric ulcer $(\mathrm{n}=41)$ & 25 & 2 & 3 & 11 & 73.2 & 92.6 \\
\hline Duodenal ulcer $(n=30)$ & 28 & 1 & 1 & 0 & 100 & 96.6 \\
\hline Gastric cancer $(n=25)$ & 16 & 1 & 1 & 7 & 72.0 & 94.1 \\
\hline Normal mucosa $(n=10)$ & 0 & 0 & 0 & 10 & 0.0 & - \\
\hline Total $(n=192)$ & 114 & 9 & 8 & 61 & 68.2 & 92.7 \\
\hline
\end{tabular}

ॠThe presence of the cag $A$ gene could not be detected as these patients were $H$ pylori positive on histology only.

showed typical changes with infiltration of PMNs and MNCs. There was no significant difference in density of $H$ pylori between the antrum and the corpus. In contrast, both MNC and PMN infiltration was significantly more severe in the antrum than in the corpus in $H$ pylori infection.

\section{H PYLORI INFECTION AND EXPRESSION OF} CHEMOKINE MRNA

$H$ pylori infection was associated with increased rates of expression of mRNA for IL-8, GRO $\alpha$, RANTES, and MIP- $1 \alpha$ in both the antrum and corpus (table 3). In contrast mRNA for MIP-1 $\beta$ and MCAF was detected in the majority of specimens independent of whether $H$ pylori infection was present or absent.

To reduce the variability because of possible differences in histology related to different diseases, we examined whether expression of these chemokine mRNAs was related to the histological findings in patients with only $H$ pylori gastritis (table 4). As was true for the overall population, in the antrum both MNC and PMN infiltration scores were significantly higher in specimens positive for the expression of IL-8 and GRO $\alpha$ mRNA. In the corpus, MNC infiltration score was similar in specimens positive or negative for expression of IL-8 or GRO $\alpha$ mRNA. When mRNA for both IL-8 and GRO $\alpha$ was expressed, the MNC and PMN infiltration scores were significantly higher in both the antrum and corpus (data not shown).

In both the antrum and corpus, the MNC infiltration score was significantly higher in specimens positive for the expression of MIP- $1 \alpha$ mRNA than in those negative for the expression of this chemokine mRNA. No relation was found in either the antrum or corpus between $\mathrm{C}-\mathrm{C}$ chemokine mRNA and PMN

Table 3 Expression of chemokine $m R N A$ and $H$ pylori infection

\begin{tabular}{|c|c|c|c|c|c|c|c|}
\hline & \multirow[b]{2}{*}{ No studied } & \multicolumn{2}{|c|}{$C-X-C$ chemokine (\%) } & \multicolumn{4}{|c|}{$C-C$ chemokine (\%) } \\
\hline & & $I L-8$ & GROa & RANTES & $M I P-1 a$ & $M I P-1 \beta$ & $M C A F$ \\
\hline \multicolumn{8}{|l|}{ Antrum } \\
\hline H pylori positive & 131 & $79.4 \ddagger$ & $77.1 \ddagger$ & $57.3+$ & $71.8 \ddagger$ & 84.0 & 95.4 \\
\hline H pylori negative & 40 & 2.5 & 0 & 25.0 & 12.5 & 82.5 & 87.5 \\
\hline \multicolumn{8}{|l|}{ Corpus } \\
\hline H pylori positive & 131 & $71.8 \ddagger$ & $76.3 \ddagger$ & $54.2^{\star}$ & $67.2 \ddagger$ & 81.7 & 96.2 \\
\hline H pylori negative & 40 & 0 & 0 & 30.0 & 10.0 & 80.0 & 85.0 \\
\hline
\end{tabular}

Chemokine expression in $H$ pylori positive specimens was compared with that in $H$ pylori negative specimens with normal histology. ${ }^{\star} \mathrm{p}<0.01, \dagger \mathrm{p}<0.0005, \ddagger \mathrm{p}<0.00001$, two tailed Fisher’s exact probability test.

Table 4 Relation between histological findings and chemokine profiles in H pylori positive patients with chronic gastritis

\begin{tabular}{|c|c|c|c|c|c|c|c|c|c|c|}
\hline & \multicolumn{4}{|c|}{$C-X-C$ chemokine } & \multicolumn{6}{|c|}{$C-C$ chemokine } \\
\hline & \multicolumn{2}{|l|}{$I L-8$} & \multicolumn{2}{|l|}{$G R O a$} & \multicolumn{2}{|c|}{ RANTES } & \multicolumn{2}{|l|}{$M I P-1 a$} & \multicolumn{2}{|l|}{$M I P-1 \beta$} \\
\hline & Positive & Negative & Positive & Negative & Positive & Negative & Positive & Negative & Positive & Negative \\
\hline \multicolumn{11}{|l|}{ No studied } \\
\hline Antrum & 39 & 11 & 40 & 10 & 27 & 23 & 38 & 12 & 40 & 10 \\
\hline Corpus & 36 & 14 & 38 & 12 & 26 & 24 & 37 & 13 & 38 & 12 \\
\hline \multicolumn{11}{|c|}{ MNC infiltration score } \\
\hline Antrum & $\begin{array}{l}2 \\
\mathrm{p}<0.0001\end{array}$ & 1.5 & $\begin{array}{l}2 \\
\mathrm{p}<0.0005\end{array}$ & 1.5 & $\begin{array}{c}2 \\
\text { NS }\end{array}$ & 2 & $\begin{array}{c}2 \\
\mathrm{p}<0.005\end{array}$ & 1.5 & $\begin{array}{c}2 \\
\text { NS }\end{array}$ & 2 \\
\hline Corpus & $\begin{array}{l}2 \\
\text { NS }\end{array}$ & 2 & $\begin{array}{l}2 \\
\text { NS }\end{array}$ & 2 & $\begin{array}{c}2 \\
\text { NS }\end{array}$ & 2 & $\begin{array}{l}2 \\
\mathrm{p}<0.001\end{array}$ & 1.5 & $\begin{array}{c}2 \\
\text { NS }\end{array}$ & 2 \\
\hline \multicolumn{11}{|c|}{ PMN infiltration score } \\
\hline Antrum & $\begin{array}{l}2 \\
\mathrm{p}<0.0001\end{array}$ & 0.5 & $\begin{array}{l}2 \\
\mathrm{p}<0.0005\end{array}$ & 0.5 & $\begin{array}{c}2 \\
\text { NS }\end{array}$ & 2 & $\begin{array}{c}2 \\
\text { NS }\end{array}$ & 2 & $\begin{array}{c}2 \\
\text { NS }\end{array}$ & 2 \\
\hline Corpus & $\begin{array}{c}1 \\
\mathrm{p}<0.05\end{array}$ & 0.5 & $\begin{array}{c}1 \\
\text { NS }\end{array}$ & 1 & $\begin{array}{c}1 \\
\text { NS }\end{array}$ & 1 & $\begin{array}{c}1 \\
\text { NS }\end{array}$ & 1 & $\begin{array}{c}1 \\
\text { NS }\end{array}$ & 1 \\
\hline \multicolumn{11}{|c|}{ H pylori density score } \\
\hline Antrum & $\begin{array}{c}2 \\
\mathrm{p}<0.01\end{array}$ & 1 & $\begin{array}{c}2 \\
p<0.005\end{array}$ & 1 & $\begin{array}{c}2 \\
\text { NS }\end{array}$ & 2 & $\begin{array}{l}2 \\
\mathrm{p}<0.0001\end{array}$ & 1 & $\begin{array}{c}2 \\
\text { NS }\end{array}$ & 1.5 \\
\hline Corpus & $\begin{array}{l}2 \\
\mathrm{p}<0.0005\end{array}$ & 1 & $\begin{array}{l}2 \\
\mathrm{p}<0.01\end{array}$ & 1 & $\begin{array}{c}2 \\
\text { NS }\end{array}$ & 2 & $\begin{array}{l}2 \\
\mathrm{p}<0.005\end{array}$ & 1 & $\begin{array}{c}2 \\
\mathrm{NS}\end{array}$ & 2 \\
\hline
\end{tabular}

Positive, specimens positive for the expression of the corresponding chemokine mRNA; negative, specimens negative for the expression of the corresponding chemokine mRNA.

Data on MCAF mRNA are not shown as all $H$ pylori positive specimens with chronic gastritis expressed MCAF mRNA.

Histological variables were scored from 0 to 3; the median score is shown.

Significance was determined using the Mann-Whitney U test. 

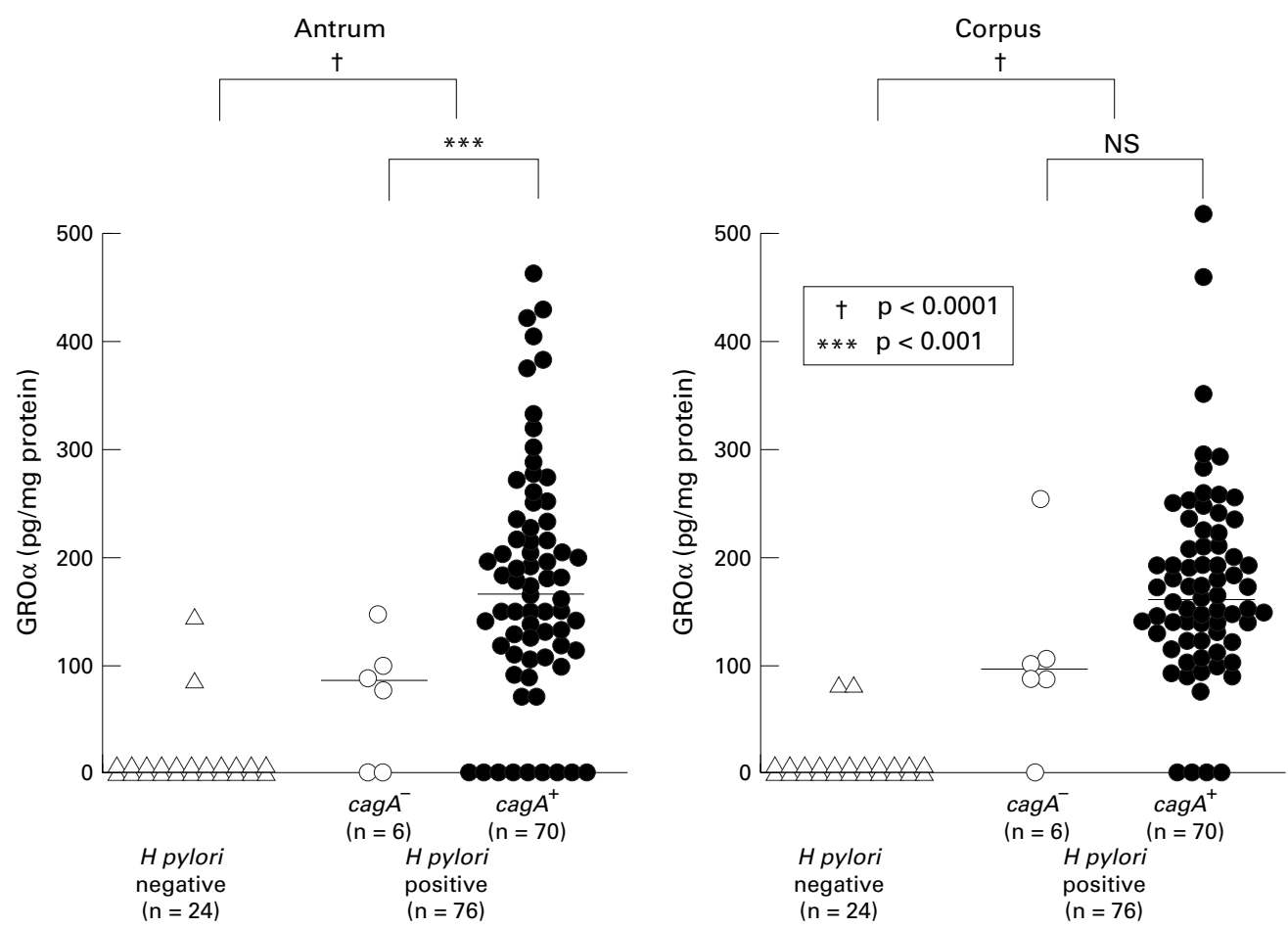

Figure 1 H pylori infection and production of GROa. Bars indicate median values for each group.

infiltration. $H$ pylori density score was significantly higher in specimens positive for the expression of IL-8, GRO $\alpha$, or MIP- $1 \alpha$ mRNA than in those negative for the expression of mRNA for these chemokines both in the antrum and corpus (table 4).

With regard to the relation between the expression of chemokine mRNA and the endoscopic findings in $H$ pylori positive specimens, the positive rate of expression of IL-8 mRNA was significantly higher in the antrum than that in the corpus in patients with duodenal ulcer $(86.7 \%$ versus $56.7 \%, \mathrm{p}<0.05, \mathrm{n}=30)$ which is consistent with the association of duodenal ulcer with antral predominant gastritis.

\section{H PYLORI INFECTION AND PRODUCTION OF} CHEMOKINES

mRNA levels of IL-8, GRO $\alpha$, RANTES, and MIP- $1 \alpha$ were increased in $H$ pylori infection and the level of production of these chemokines was examined at the protein level by ELISA in 100 patients, 76 of whom were infected with $H$ pylori. There were no significant differences in sex or age distribution between these patients and the total patient population. The mucosal levels of IL-8 and GRO $\alpha$ protein were significantly increased in $H$ pylori infection in the antrum and corpus (median for IL- 8 was $58 \mathrm{pg} / \mathrm{mg}$ versus $0 \mathrm{pg} / \mathrm{mg}$, and $60.6 \mathrm{pg} / \mathrm{mg}$ versus $0 \mathrm{pg} / \mathrm{mg}$ for antrum and corpus, respectively; $\mathrm{p}<0.0001)$. For GRO $\alpha$ the median was $157.3 \mathrm{pg} / \mathrm{mg}$ versus $0 \mathrm{pg} / \mathrm{mg}$ and $157.4 \mathrm{pg} / \mathrm{mg}$ versus $0 \mathrm{pg} / \mathrm{mg}$ for antrum and corpus, respectively ( $\mathrm{p}<0.0001$; fig 1$)$. In addition, the mucosal levels of IL- 8 and GRO $\alpha$ protein were significantly higher in specimens positive for expression of IL- 8 and GRO $\alpha$ mRNA compared with those in specimens without expression of these transcripts (median for IL-8 was $84.5 \mathrm{pg} / \mathrm{mg}$ versus $0 \mathrm{pg} / \mathrm{mg}$, and $88.5 \mathrm{pg} / \mathrm{mg}$ versus $0 \mathrm{pg} / \mathrm{mg}$ for antrum and corpus, respectively; $\mathrm{p}<0.0001)$. For GRO $\alpha$ the median was $183.1 \mathrm{pg} / \mathrm{mg}$ versus $0 \mathrm{pg} / \mathrm{mg}$ and $180 \mathrm{pg} / \mathrm{mg}$ versus $96.4 \mathrm{pg} / \mathrm{mg}$ for antrum and corpus, respectively $(\mathrm{p}<0.0001)$. The mucosal level of GRO $\alpha$ protein was significantly higher in cagA positive than in cagA negative specimens in the antrum (fig 1).

The mucosal level of IL- 8 protein was significantly correlated with that of GRO $\alpha$ protein both in the antrum and corpus $(p<0.0001$ by Spearman rank test; fig 2). There was no relation between the level of mucosal RANTES protein between $H$ pylori infected and uninfected individuals (median $251.8 \mathrm{pg} / \mathrm{mg}$ versus $256.1 \mathrm{pg} / \mathrm{mg}$ and $286.4 \mathrm{pg} / \mathrm{mg}$ versus 293.3 $\mathrm{pg} / \mathrm{mg}$ for antrum and corpus, respectively). In the antrum, the RANTES protein level was significantly higher in specimens positive for the expression of RANTES mRNA than in those negative by RANTES RT-PCR (median $282.3 \mathrm{pg} / \mathrm{mg}$ versus $228.8 \mathrm{pg} / \mathrm{mg}$, respectively, $\mathrm{p}<0.05)$. The mucosal level of MIP-1 $\alpha$ protein was below the threshold of sensitivity in all specimens.

In the corpus, mucosal levels of IL- 8 and GRO $\alpha$ protein were significantly lower in patients with duodenal ulcer compared with those in patients with gastritis without ulcers (median for IL-8 of $10.1 \mathrm{pg} / \mathrm{mg}$ versus 90 $\mathrm{pg} / \mathrm{mg}$, and median for GRO $\alpha$ of $102.4 \mathrm{pg} / \mathrm{mg}$ versus $167 \mathrm{pg} / \mathrm{mg}$, for antrum and corpus respectively; $\mathrm{p}<0.05)$. On the other hand, the mucosal levels of IL-8 protein were significantly higher in patients with duodenal ulcer compared with those in patients with gastritis without ulcers in the antrum (median 102.3 $\mathrm{pg} / \mathrm{mg}$ versus $59.9 \mathrm{pg} / \mathrm{mg}$; $\mathrm{p}<0.05)$. 
Antrum

$r=0.737, \mathrm{p}<0.0001, \mathrm{n}=76$

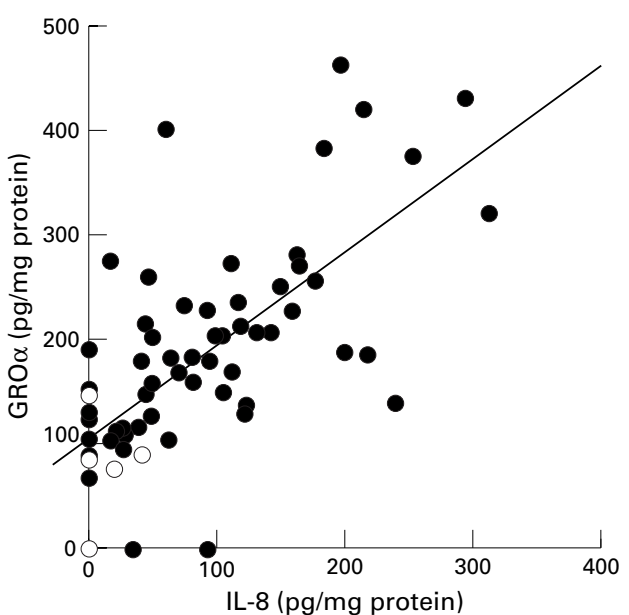

Corpus $r=0.573, \mathrm{p}<0.0001, \mathrm{n}=76$

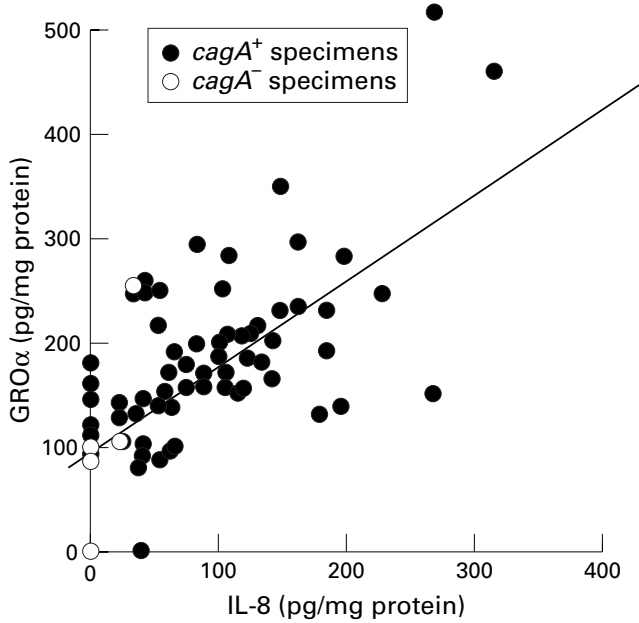

Figure 2 Relation between mucosal levels of IL-8 and GROa protein in $H$ pylori positive patients.

We examined the relation between the production of chemokines and histological findings in $H$ pylori chronic gastritis. The mucosal levels of IL-8 and GRO $\alpha$ protein were significantly correlated with infiltration of MNCs and PMNs in the antrum (fig 3). There was no significant difference in the corpus. The mucosal levels of IL- 8 and GRO $\alpha$ protein were significantly correlated with the density of $H$ pylori in both the antrum and corpus. $H$ pylori positive specimens with diseases other than chronic gastritis also showed a similar tendency (data not shown).
EXPRESSION AND PRODUCTION OF CHEMOKINES AND ERADICATION OF H PYLORI

Twenty patients were treated with eradication therapy. Ten had gastric ulcer and 10 had duodenal ulcer; all patients were infected with $H$ pylori possessing the cagA gene. $H$ pylor $i$ infection was successfully cured in 15 patients, seven with gastric ulcer and eight with duodenal ulcer. The positive rates of expression of IL-8, GRO $\alpha$, and MIP- $1 \alpha$ mRNA decreased significantly following successful treatment of patients (data not shown). There was no significant change in the expression of
Antrum
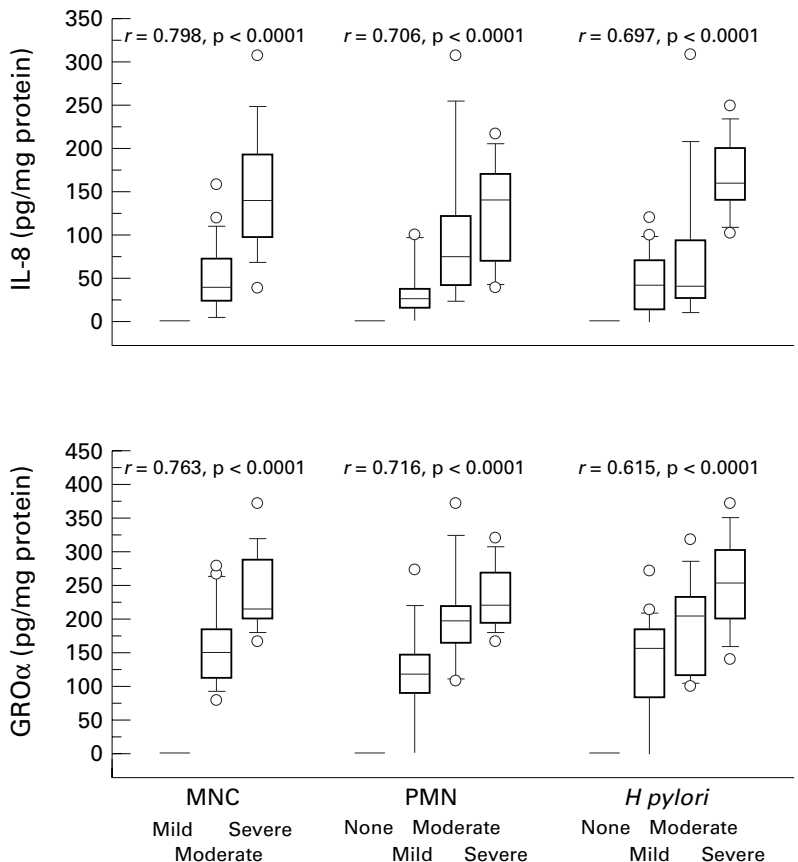

Corpus
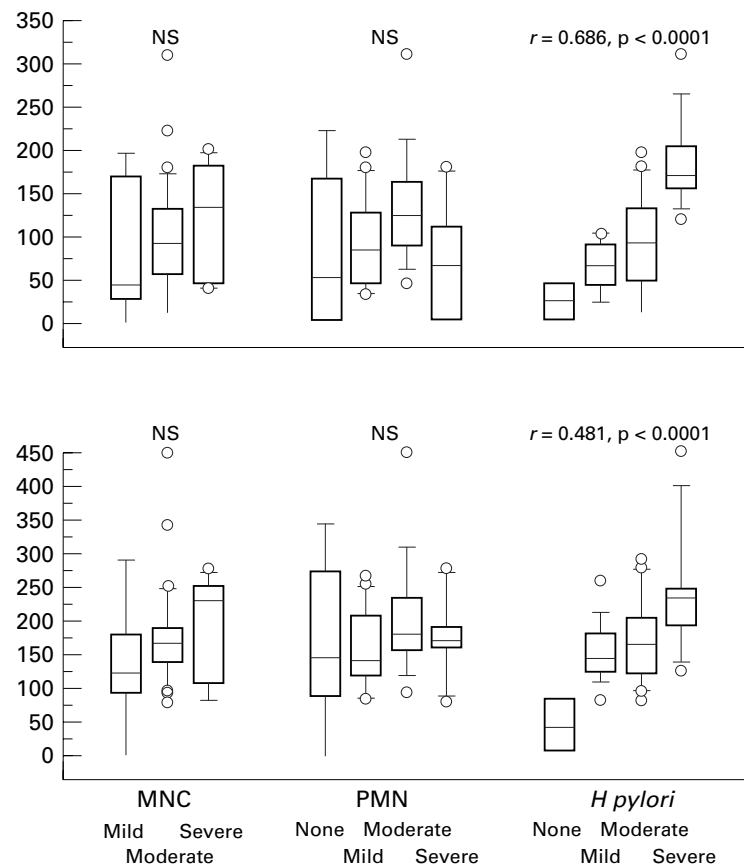

Figure 3 Production of $C-X-C$ chemokines and histological findings in $H$ pylori positive patients with chronic gastritis are expressed as box plots. The ends of the bars indicate the 25th and 75th percentiles. The 50th percentile is indicated with a line, and the 10th and 90th percentiles are indicated with error bars. Data outside the 10th and 90th percentile are displayed using symbols. Correlation coefficients were calculated with the Spearman rank test. 

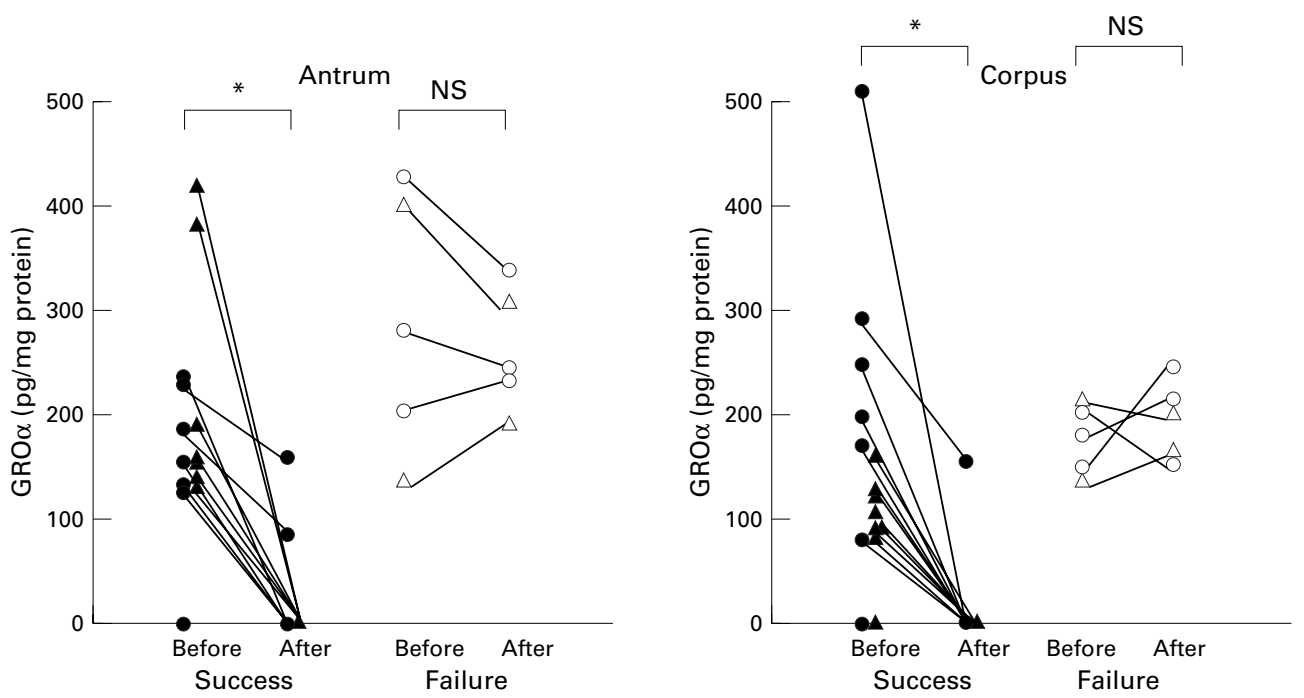

- $\circ$ Gastric ulcer, $\Delta \triangle$ Duodenal ulcer

Figure 4 Production of GROa and eradication of H pylori. ${ }^{*} p<0.005$ by Wilcoxon's matched pairs test. Before, before eradication therapy; after, after eradication therapy.

RANTES, MIP- $1 \beta$, and MCAF mRNA. The mucosal levels of IL-8 and GRO $\alpha$ protein fell below the level of detection in all but one and two patients, respectively (fig 4). The mucosal level of RANTES protein was not reduced even in successfully treated patients.

\section{EXPRESSION AND PRODUCTION OF CHEMOKINES} AND THE cagA GENE

As expected, the positive rate of expression of IL-8 mRNA was significantly higher in $\operatorname{cag} A$ gene positive strains ( $c a g A^{+}$specimens) than in $\operatorname{cag} A$ gene negative strains ( $\operatorname{cag} A^{-}$specimens) in the antrum $(86.8 \%$ versus $44.4 \%, \mathrm{p}<0.005)$. Similarly, the mucosal levels of IL-8 protein were also significantly increased in $\mathrm{cag} A^{+}$compared with cag $A^{-}$specimens in both the antrum and corpus (median $65.3 \mathrm{pg} / \mathrm{mg}$ versus 0 $\mathrm{pg} / \mathrm{mg}$ and $73.7 \mathrm{pg} / \mathrm{mg}$ versus $10 \mathrm{pg} / \mathrm{mg}$ for antrum and corpus, respectively; $\mathrm{p}<0.05)$. The positive rate for expression of GRO $\alpha$ mRNA was significantly higher in $\operatorname{cag} A^{+}$than in $\operatorname{cag} A^{-}$ specimens in the corpus $(83.3 \%$ versus $44.4 \%$, $\mathrm{p}<0.05)$. The mucosal level of GRO $\alpha$ protein was significantly increased in $\operatorname{cag} A^{+}$over that in cag $A^{-}$specimens in the antrum (median 173.2 $\mathrm{pg} / \mathrm{mg}$ versus $83.0 \mathrm{pg} / \mathrm{mg}, \mathrm{p}<0.001$; fig 1$)$. Expression of C-C chemokine mRNA did not differ between $\operatorname{cag} A^{+}$and $\operatorname{cag} A^{-}$specimens in either the antrum or corpus.

\section{Discussion}

In the present study, $H$ pylori infection was associated with increased expression and production of not only the C-X-C chemokine IL-8 but also GRO $\alpha$. Furthermore, the expression of $\mathrm{C}-\mathrm{X}-\mathrm{C}$ chemokines significantly decreased in patients after successful eradication. These findings are consistent with the C-X-C chemokines playing important roles in $\mathrm{H}$ pylori associated gastric inflammation. The degree of cellular infiltration was however lower in the corpus than that in the antrum but there were no differences in expression of C-X-C chemo- kines between these areas, suggesting that other, as yet unidentified, factors modulate the mucosal response between C-X-C chemokine expression and cellular infiltration. It is of interest that the mucosal levels of C-X-C chemokines correlated significantly with the density of $H$ pylori in both the antrum and corpus, whereas the mucosal levels of C-X-C chemokines were significantly correlated with cellular infiltration only in the antrum. However, even in the corpus, expression of both IL- 8 and GRO $\alpha$ mRNA was associated with significantly more severe MNC and PMN infiltration, suggesting that IL-8 and GRO $\alpha$ may act cooperatively and that their synergistic action causes severe inflammation even in the corpus with low responsiveness to either chemokine alone. There are two types of IL-8 receptor: type I is IL-8 specific and type II has affinity for GROa. ${ }^{29}$ Further studies will be necessary to investigate whether the numbers of these receptors differ between the antrum and corpus and whether such a difference might be related to the differences in inflammatory response to $H$ pylori between these two areas of the stomach.

With regard to $\mathrm{C}-\mathrm{C}$ chemokines, the positive rate of expression of MIP- $1 \alpha$ mRNA was significantly enhanced in $H$ pylori positive specimens. Furthermore, the positive rate of expression of MIP-1 $\alpha$ mRNA significantly decreased after successful eradication. The MNC infiltration score was significantly higher in specimens positive for the expression of MIP- $1 \alpha$ mRNA compared with those negative for its expression in both the antrum and corpus. Expression of MIP- $1 \alpha$ mRNA was not associated with PMN infiltration. These data are in agreement with previous observations that MIP- $1 \alpha$ has chemotactic activity for MNCs but has little effect on PMNs. ${ }^{20}$ However, as production of MIP-1 $\alpha$ protein was below the threshold of sensitivity in all patients, the role of this chemokine cannot be determined from this study. 
While the positive rate of expression of RANTES mRNA was significantly higher in $H$ pylori positive infection, there were no differences in protein levels. The mucosal level of RANTES protein was significantly higher in specimens positive for the expression of RANTES mRNA than in those negative for the expression of this mRNA in the antrum. Similar conflicting data have been reported for some other cytokines including $\mathrm{IL}-1 \alpha,{ }^{13}$ IL-7, ${ }^{14}{ }^{15}$ and IL-10. ${ }^{14}{ }^{15}$ These conflicts between protein and mRNA levels are possibly related to disturbances in the pathway from mRNA to protein expression, degradation of mRNA prior to translation into protein, or the fact that the amount of mRNA may not exceed the threshold required for protein production.

We found no correlation between RANTES mRNA and protein expression; the degree of MNC and PMN infiltration and the levels of expression of RANTES were not decreased after successful eradication therapy. These findings suggest that RANTES may not play a role in MNC or PMN infiltration in $H$ pylori infection. RANTES does not show any chemotactic activity on PMNs, ${ }^{30}$ but shows chemotactic activity on $\mathrm{T}$ lymphocytes ${ }^{31}$ and eosinophils. ${ }^{30}{ }^{32}$ Further studies will be necessary to investigate the relation between infiltration by these cells and RANTES expression in gastric mucosa.

MIP-1 $\beta$ and MCAF mRNA were detected in the majority of specimens regardless of the presence or absence of $H$ pylori. It has been thought that chemokines are not expressed in normal cells, but as the stomach is constantly exposed to various stimuli including dietary components, these influences may induce expression of chemokine mRNA.

In the antrum, the mucosal levels of IL- 8 and GRO $\alpha$ protein, the positive rate of expression of IL- 8 mRNA, and $H$ pylori density were all significantly higher in patients with duodenal ulcer than in those with other diseases. In contrast, in the corpus, the mucosal levels of IL-8 protein and $H$ pylori density were significantly lower in patients with duodenal ulcer than in those with other diseases. It is not clear what relation may exist between these observations and the formation of duodenal ulcer disease in this study.

Finally, we examined the $\operatorname{cag} A$ gene. Recent studies using cag $A$ isogenic mutant strains indicated that the $\operatorname{cag} A$ gene was not essential for induction of IL-8, but was a phenotypic marker for $H$ pylori strains capable of inducing IL-8. ${ }^{33}$ Genes coexpressed with the $\operatorname{cag} A$ gene, present in the upstream sequence of the cag $A$ gene, are thought to contribute to IL- 8 induction. ${ }^{34}{ }^{35}$ Recently, a region of approximately 40 kilobases responsible for virulence that contains the $\operatorname{cag} A$ genes was reported and is referred to as the " $c a g$ pathogenicity island". ${ }^{36} \operatorname{cag} A$ positive strains are, therefore, regarded as strains possessing the cag pathogenicity island. In agreement with previous studies, ${ }^{13-15}$ expression and production of IL-8 were enhanced by $\operatorname{cag} A$ positive strains compared with $\operatorname{cag} A$ negative strains. In this study the positive rate of expression of GRO $\alpha$ mRNA in the corpus and the mucosal level of GRO $\alpha$ protein in the antrum was also significantly higher in infection with cag $A$ positive $H$ pylori. There was no association between C-C chemokines and the $\operatorname{cag} A$ gene.

In conclusion, $H$ pylori infection is associated with increased expression and production of C-X-C chemokines IL- 8 and GRO $\alpha$, but not C-C chemokines. Although $H$ pylori induces $\mathrm{C}-\mathrm{X}-\mathrm{C}$ chemokines both in the antrum and corpus, the association between chemokine expression and inflammation is less in the corpus.

We thank Professor David Y Graham, Baylor College of Medicine, for his many helpful discussions and assistance with the manuscript. Part of this work was presented at the Annual Meeting of the American Gastroenterological Association, Washington DC, May 1997, and appeared in abstract form in Gastroenterology 1997;112:A336.

1 Blaser MJ. Epidemiology and pathophysiology of Campylobacter pylori infections. Rev Infect Dis 1990;12(suppl 1):99-106.

2 Peterson WL. Helicobacter pylori and peptic ulcer disease. N Engl f Med 1991;324:1043-8.

3 Nomura A, Stemmermann GN, Chyou PH, et al. Helicobacter pylori infection and gastric carcinoma among Japanese Americans in Hawaii. N Engl f Med 1991;325:1132-6.

4 Parsonnet J, Friedman GD, Vandersteen DP, et al. Helicobacter pylori infection and the risk of gastric carcinoma. N Engl F Med 1991;325:1127-31.

5 Rauws EAJ, Langenberg W, Houthoff HJ, et al. Campylobacter pyloridis - associated chronic active antral gastritis. Gastroenterology 1988;94:33-40.

6 Crabtree JE, Shallcross TM, Heatley RV, et al. Mucosal tumour necrosis factor alpha and interleukin-6 in patients with Helicobacter pylori associated gastritis. Gut 1991;32: 1473-7.

7 Crabtree JE, Peichl P, Wyatt JI, et al. Gastric interleukin-8 and IgA IL-8 autoantibodies in Helicobacter pylori infection. Scand f Immunol 1993;37:65-70.

8 Noach LA, Bosma NB, Jansen J, et al. Mucosal tumor necrosis factor-alpha, interleukin-1 beta, and interleukin-8 necrosis factor-alpha, interleukin-1 beta, and interleukin- 8
production in patients with Helicobacter pylori infection. production in patients with Helicobacte

9 Gionchetti P, Vaira D, Campieri M, et al. Enhanced mucosal interleukin-6 and -8 in Helicobacter pylori-positive dyspeptic patients. Am $\mathcal{F}$ Gastroenterol 1994;89:883-7.

10 Fan XG, Chua A, Fan XJ, et al. Increased gastric production of interleukin-8 and tumor necrosis factor in patients with Helicobacter pylori infection. F Clin Pathol 1995;48:133-6.

11 Moss SF, Legon S, Davies J, et al. Cytokine gene expression in Helicobacter pylori associated antral gastritis. Gut 1994; 35:1567-70.

12 Yamaoka Y, Kita M, Kodama T, et al. Expression of cytokine mRNA in gastric mucosa with Helicobacter pylori infection. Scand f Gastroenterol 1995;30:1153-9.

13 Peek RM, Miller GG, Tham KT, et al. Heightened inflammatory response and cytokine expression in vivo to cagA ${ }^{+}$Helitory response and cytokine expression in vivo to cag
cobacter pylori strains. Lab Invest 1995;71:760-70.

cobacter pylori strains. Lab Invest 1995;71:760-70.
14 Yamaoka Y, Kita M, Kodama T, et al. Helicobacter pylori cagA gene and expression of cytokine messenger RNA in gastric mucosa. Gastroenterology 1996;110:1744-52.

15 Yamaoka Y, Kita M, Kodama T, et al. Induction of various cytokines and development of severe mucosal inflammation by cagA gene-positive Helicobacter pylori strains. Gut 1997;41:442-51.

16 Matsushima K, Oppenheim JJ. Interleukin 8 and MCAF: novel inflammatory cytokines inducible by IL-1 and TNF. Cytokine 1989;1:2-13.

17 Baggiolini M, Watz A, Kunkel SL. Neutrophil-activating peptide-1/interleukin 8, a novel cytokine that activates neutrophils. $\mathcal{F}$ Clin Invest 1989;84:1045-9.

18 Schall TJ. Biology of the RANTES/SIS cytokine family. Cytokine 1991;3:165-83.

19 Baggioline M, Dewald B, Moser B. Interleukin-8 and Baggioline $M$, Dewald $B$, Moser $B$. Interleukin-8 and
related chemotactic cytokines-CXC and CC chemokines. Adv Immunol 1994;55:97-179.

20 Taub DD, Oppenheim JJ. Chemokines, inflammation and Taub DD, Oppenheim JJ. Chemokines, inflammation
the immune system. Ther Immunol 1994;1:229-46.

21 Stolte M, Eidt S, Ohnsmann A. Differences in $\mathrm{H}$ pylori-associated gastritis in the antrum and body of the stomach. Z Gastroenterol 1990;28:229-33.

22 Bayerdorffer E, Lehn N, Hatz R, et al. Difference in expression of Helicobacter pylori gastritis in antrum and body. Gastroenterology 1992;102:1575-82.

23 Dixon MF, Genta RM, Yardley JH, et al. Classification and grading of gastritis. The updated Sydney System. Am $\mathcal{F}$ Surg Pathol 1996;20:1161-81.

24 Chomczynski P, Sacchi N. Single-step method of RNA isolation by acid guanidinium thiocyanate-phenol-chloroform
extraction. Anal Biochem 1987;162:156-9.

25 Tummuru MK, Cover TL, Blaser MJ. Cloning and expression of a high-molecular-mass major antigen of Helicobacter pylori: evidence of linkage to cytotoxin production. Infect Immun 1993;61:1799-809. 
26 Kita M, Hayashi T, Yamagishi H, et al. Expression de l'ARN messager des cytokines dans la rate humaine $C R$ Soc Biol messager des cyto

27 Hosaka S, Akahoshi T, Wada C, et al. Expression of the chemokine superfamily in rhematoid arthritis. Clin Exp Immunol 1994;97:451-7.

28 Hoshina S, Kahn SM, Jiang W, et al. Direct detection and amplification of Helicobacter pylori ribosomal $16 \mathrm{~S}$ gene segments from gastric endoscopic biopsies. Diagn Microbio Infect Dis 1990;13:473-9.

29 Lee J, Horuk R, Rice GC, et al. Characterization of two high affinity human interleukin-8 receptors. F Biol Chen 1992;267:16283-7.

30 Kameyoshi Y, Dàrschner A, Mallet AI, et al. Cytokine RANTES related by thrombin-stimulated platelets is an attractant for human eosinophils. F Exp Med 1992;176: 587-92.

31 Schall TJ, Bacon K, Toy KJ, et al. Selective attraction of monocytes and $\mathrm{T}$ lymphocytes of the memory phenotype by cytokine RANTES. Nature 1990;347:669-71.
32 Rot A, Krieger M, Brunner $\mathrm{T}$, et al. RANTES and macrophage inflammatory protein $1 \mathrm{a}$ induce the migration and activation of normal human eosinophil granulocytes. $\mathcal{F}$ Exp Med 1992;176:1489-95.

33 Sharma SA, Tummuru MK, Miller GG, et al. Interleukin-8 response of gastric epithelial cell lines to Helicobacter pylori stimulation in vitro. Infect Immun 1995;63:1681-7.

34 Crabtree JE, Xiang Z, Lindley IJD, et al. Induction of interleukin-8 secretion from gastric epithelial cells by a cagA negative isogenic mutant of Helicobacter pylori. $\mathfrak{f}$ cagA negative isogenic muta
Clin Pathol 1995;48:967-9.

35 Tummuru MK, Sharma SA, Blaser MJ. Helicobacter pylori picB, a homolog of the Bordetella pertussis toxin secretion protein, is required for induction of IL-8 in gastric epithelial cells. Mol Microbiol 1995;18:867-76.

36 Censini S, Lange C, Xiang Z, et al. cag, a pathogenicity island of Helicobacter pylori, encodes type I-specific and disease-associated virulence factors. Proc Natl Acad Sci USA 1996;93:14648-53. 